\title{
EVALUASI PENGADAAN BAHAN KONSTRUKSI PADA PROYEK RUMAH SAKIT UNGGUL KARSA MEDIKA
}

\author{
Maksum Tanubrata ${ }^{1}$ Rian Adhita Trisyandi ${ }^{2}$ \\ ${ }^{1}$ Dosen Program Studi S-1 Teknik Sipil, Fakultas Teknik,Universitas Kristen \\ Maranatha Jl.Prof.Drg.Suriasumantri no 65 Bandung,40164 \\ Email: maksum.tanubrata150@gmail.com \\ ${ }^{2}$ Alumni Program Studi S-1 Teknik Sipil, Fakultas Teknik, Universitas Kristen \\ Maranatha Jl.Prof.Drg.Suriasumantri no 65 Bandung,40164
}

\begin{abstract}
ABSTRAK
Manajemen bahan konstruksi yang baik merupakan syarat utama untuk menghasilkan penanganan bahan konstruksi yang baik meliputi segi kualitas biaya, waktu, spesifikasi, dan jumlah bahan konstruksi merupakan usaha penting untuk menghasilkan manajemen bahan yang baik. Tujuan Tugas Akhir ini adalah untuk mengetahui hal-hal yang diperlukan dalam proses pengadaan bahan konstruksi pada proyek Rumah Sakit Unggul Karsa Medika. Analisis data meliputi hal-hal yang diperlukan untuk mengevaluasi proses perencanaan, proses pembelian bahan, proses pengiriman bahan, proses penyimpanan bahan, proses pengeluaran bahan, dan metode pengendalian dalam memenuhi kebutuhan bahan. Hasil penelitian didapat proses pengadaan bahan material yang terjadi di lapangan menunjukkan bahwa pengadaan bahan konstruksi pada proyek Rumah Sakit Unggul Karsa Medika sudah baik, meskipun masih ada hal-hal yang perlu diperbaiki lagi dalam pelaksanaannya di lapangan.
\end{abstract}

Kata Kunci: manajemen bahan, pengadaan, proses

\begin{abstract}
Good construction material management is the main requirement to produce good handling of construction materials in terms of quality of cost, time, specification, and quantity of construction materials is an important effort to produce good material management. The purpose of this Final Project is to know the things needed in the process of procurement of construction materials at the project Hospital Unggul Karsa Medika. Data analysis includes the things needed to evaluate the planning process, material purchasing process, material delivery process, material storage process, material expenditure process, and control methods to meet material requirements. The result of the research shows that the material procurement process that occurred in the field shows that the procurement of construction materials at the Hospital project of Unggul Karsa Medika is good, although there are still things that need to be improved again in the implementation in the field.
\end{abstract}

Keywords: materials management, procurement, process

\section{PENDAHULUAN}

\subsection{Latar Belakang}

Pelaksana setiap proyek mencakup pengadaan dan pemrosesan bahan-bahan yang menjadi bagian dari bangunan. Pemakaian material merupakan bagian terpenting yang mempunyai persentase cukup besar dari total biaya proyek. Dari beberapa penelitian

Evaluasi Pengadaan Bahan Konstruksi Pada Proyek Rumah Sakit Unggul Karsa Medika 
menyatakan bahwa biaya material menyerap $50-70 \%$ dari biaya proyek, biaya ini belum termasuk biaya penyimpanan material. Penggunaan teknik manajemen yang baik dan tepat untuk membeli, menyimpan, mendistribusikan, dan menghitung material konstruksi menjadi sangat penting, karena nantinya dapat berpengaruh besar pada biaya pelaksanaan proyek (Ervianto, 2004).

Penyediaan bahan bangunan pada proyek konstruksi memerlukan manajemen yang baik untuk menunjang kelancaran pekerjaan. Dalam proyek konstruksi, bahan merupakan bagian terbesar dari total biaya poyek. Sehingga sudah semestinya bila perusahaan menaruh perhatian besar terhadap proses pengadaannya, termasuk juga dalam menyiapkan dan menangani dokumen yang diperlukan (Suharto, 1995).

Disamping itu, bahan juga bersifat fluktuatif dan rawan terhadap kenaikan harga, sehingga berada dalam jalur kritis dan mendominasi kebutuhan proyek. Kenaikan harga bahan harus diantisipasi pada saat tender, pemesanan, maupun penyimpanan, terutama untuk bahan seperti semen dan besi beton.

Oleh karena itu, dilakukan penelitian mengenai bagaimana kebijakan pengadaan bahan konstruksi saat pembangunan Rumah Sakit Unggul Karsa Medika, dengan cara mengevaluasi proses pengadaan bahan konstruksi untuk mengetahui apakah kebijakan pengadaan bahan sudah sesuai atau tidak.

\subsection{Tujuan Penelitian}

Berdasarkan uraian latar belakang tujuan penelitian ini adalah mengevaluasi proses pengadaan bahan konstruksi yang digunakan di lapangan atau proyek.

\subsection{Ruang Lingkup Penelitian}

Ruang lingkup penelitian adalah:

1. Proyek konstruksi yang ditinjau adalah proyek Rumah Sakit Unggul Karsa Medika;

2. Pada penelitian ini obyek penelitian dibatasi pada kinerja prosedur pengadaan bahan yang diterapkan pada proyek;

3. Total volume kebutuhan bahan dan biaya kebutuhan bahan pada pembangunan Rumah Sakit Unggul Karsa Medika tidak dibahas, karena Tugas Akhir ini hanya membahas evaluasi kebijakan prosedur pengadaan bahan konstruksi;

4. Material bahan yang digunakan tersedia dipasaran sehingga tidak memerlukan bahan pengganti.

\section{TINJAUAN PUSTAKA}




\subsection{Manajemen Bahan Konstruksi}

\subsubsection{Pengertian}

Manajemen dapat diartikan sebagai kemampuan untuk memperoleh suatu hasil dalam rangka pencapaian tujuan tertentu melalui kegiatan sekelompok orang. Tujuan yang akan dicapai ditetapkan terlebih dahulu sebelum melibatkan sekelompok orang yang memiliki kemampuan atau keahlian masing-masing untuk mencapai hasil sesuai dengan tujuan yang telah ditetapkan. Manajemen berfungsi untuk melaksanakan semua kegiatan yang bertujuan untuk mencapai hasil yang diinginkan (George R. Terry, 1994)

Bahan konstruksi (construction material) meliputi semua bahan yang akan digunakan untuk pelaksanaan kegiatan membangun suatu bangunan. Bahan konstruksi yang digunakan dalam proses pembangunan suatu proyek dapat dibedakan menjadi dua, yaitu: bahan yang kelak akan menjadi bagian tetap dari struktur (permanent material), seperti: semen, batu bata, tulangan baja, dan lain-lain dan bahan yang dibutuhkan kontraktor dalam proses pembangunan proyek tetapi tidak akan menjadi bagian struktur (bahan sementara), seperti: papan untuk bekisting, perancah, bahan peledak, dan lain-lain. Dari uraian di atas, manajemen bahan konstruksi dapat diartikan sebagai pengelolaan bahan yang akan digunakan untuk pelaksanaan konstruksi dengan cara atau metode tertentu agar diperoleh suatu penanganan bahan yang baik, meliputi segi waktu, biaya, kualitas, ataupun spesifikasi dan jumlah bahan, sehingga proses konstruksi dapat berjalan tanpa adanya kendala dari sektor bahan.

\subsubsection{Lingkup Manajemen Bahan Konstruksi}

Dalam manajeman bahan konstruksi terdapat berbagai proses yang harus dilaksanakan dengan baik. Secara umum, terdapat 3 tahap penting dalam proses manajemen bahan konstruksi, yaitu:

1. Pengadaan atau pembelian bahan yang meliputi:

a. Perencanaan pembelian, merupakan perencanaan bahan yang akan dibeli, antara lain: perencanaan spesifikasi, kuantitas, waktu pengadaan, dan biaya bahan.

b. Pembelian bahan (material purchasing), berupa pencarian informasi bahan yang akan dibeli, pemilihan pemasok atau supplier, dan melakukan transaksi pembelian.

2. Penerimaan bahan

Merupakan tahap transisi, ditandai dengan selesainya proses pembelian bahan dan bahan akan disimpan dan siap digunakan untuk kegiatan konstruksi.

Evaluasi Pengadaan Bahan Konstruksi Pada Proyek Rumah Sakit Unggul Karsa Medika (Maksum Tanubrata, Rian Adhita Trisyandi) 
3. Penyimpanan bahan sampai bahan diserahkan ke lini pelaksanaan proyek, meliputi:

a. penyimpanan bahan.

b. pengeluaran bahan dan penyerahan ke lini pelaksanaan proyek.

\subsubsection{Pelaku Manajemen Bahan Konstruksi dalam Tim Kerja Proyek}

Dalam suatu organisasi manajemen proyek berukuran cukup besar terdapat berbagai departemen yang mempunyai tugas dan peran masing-masing dalam mendukung pelaksanaan proyek. Manajemen bahan konstruksi biasanya ditangani oleh bagian pengadaan suatu organisasi manajemen proyek, baik untuk tim inti proyek kantor pusat maupun tim inti proyek engineering-konstruksi di lapangan, sedangkan koordinasi dan pengendalian mutu bahan merupakan tanggung jawab bagian pengawasan dan pengendalian mutu.

Di kantor pusat, bagian pembelian (pengadaan) bekerja sama dengan engineering untuk menyusun paket pembelian, tender, dan mengkaji vendor drawing (gambar material dari supplier) dalam rangka membeli material proyek. Kegiatan tersebut dilakukan di kantor pusat sehingga koordinasi, komunikasi, dan integrasi mudah dilakukan. Bila tahap kegiatan manajemen bahan telah selesai, yang diperlukan untuk konstruksi mulai dipindahkan ke lapangan/lokasi proyek. Pengadaan lapangan bertanggung jawab atas pengadaan material di lokasi (local purchase) dan tindak lanjut pemesanan material dari kantor pusat, serta penanganan material di lokasi proyek.

\subsubsection{Kontrol Terhadap Proses Manajemen Bahan Konstruksi}

Proses manajemen bahan konstruksi agar dapat berjalan dengan baik harus dikontrol, baik oleh bagian manajemen bahan sendiri maupun oleh pengawas dan pengendalian mutu material di lapangan. Kontrol dilakukan sejak perencanaan pembelian, seperti kontrol terhadap bentuk informasi bahan yang akan dibeli dan supplier bahan sampai dengan kontrol material di lapangan, seperti: kontrol terhadap penyimpanan bahan dan kontrol terhadap proses pengeluaran bahan sampai diserahkan ke pelaksana konstruksi. 
Kontrol dilakukan agar setiap proses manajemen bahan konstruksi dapat dijalankan sesuai dengan prosedur yang ada, sehingga kualitas, kuantitas, waktu pengadaan, dan biaya material benar-benar sesuai dengan rencana atau bahkan dapat lebih baik. Langkah-langkah dan hal-hal yang diperlukan untuk mengontrol proses manajemen bahan konstruksi sebaiknya disusun dengan baik, sehingga dapat dijalankan tanpa ada kendala dalam pelaksanaannya dan dapat dihasilkan suatu penanganan bahan konstruksi yang baik sehingga secara umum dapat melancarkan pelaksanaan kegiatan proyek.

Langkah-langkah dan hal-hal yang diperlukan untuk mengontrol proses manajemen bahan konstruksi meliputi kontrol terhadap bentuk informasi bahan, kontrol terhadap proses pembelian, kontrol terhadap kualitas dan spesifikasi bahan, kontrol terhadap manajemen kualitas bahan, kontrol terhadap proses pemeriksaan dan pengujian bahan, kontrol terhadap proses penerimaan akhir, kontrol terhadap penyimpanan bahan, dan kontrol terhadap pengeluaran bahan.

\subsection{Pengadaan Bahan Konstruksi}

Dalam struktur organisasi manajemen proyek mempunyai peranan sangat penting dalam penanganan bahan konstruksi yang akan menjadi salah satu syarat penting dalam pelaksanaan kegiatan konstruksi. Pengadaan bahan konstruksi dapat dilakukan dengan dua cara, yaitu:

1. Produksi sendiri, yaitu dengan memproduksi sendiri bahan konstruksi yang diperlukan untuk kegiatan konstruksi. Pada umumnya dalam suatu proyek yang diperlukan untuk kegiatan konstruksi, material yang diproduksi sendiri oleh pelaksana adalah sangat kecil, baik jenis ataupun kuantitas materialnya. Bahan konstruksi yang diproduksi sendiri biasanya dilakukan langsung di lokasi proyek. Bahan konstruksi yang dapat diproduksi sendiri antara lain: batako, paving block, dll.

2. Pembelian, yaitu dengan membeli bahan konstruksi dari pemasok atau supplier bahan konstruksi. Pembelian sangat penting karena sebagian besar bahan konstruksi yang diperlukan untuk kegiatan konstruksi diperoleh dengan cara membeli. Proses pembelian harus benar-benar ditangani dengan baik, sejak perencanaan pembelian, pembelian, sampai dengan proses pengantaran bahan ke lokasi proyek. Proses 
pembelian sendiri mempunyai lingkup cukup luas, yaitu sejak perencanaan bahan yang akan dibeli, sampai bahan diantar ke proyek.

Kegiatan pembelian mempunyai pengaruh sangat besar terhadap mutu manajemen proyek secara total. Dalam pelaksanaan suatu proyek konstruksi, biaya bahan konstruksi mempunyai bobot sangat besar, dapat berkisar antara 50\% sampai $70 \%$ dari total biaya proyek. Oleh karena itu, departemen manajemen bahan tidak hanya berperan secara efektif dalam proses pembelian tetapi harus bertanggung jawab terhadap mutu material, harga, dan penyerahan pada waktu yang tepat untuk pelaksanaan pembangunan.

\subsubsection{Fungsi Pembelian}

Terdapat perbedaan mendasar berkaitan dengan fungsi pembelian dan departemen pengadaan, sebagai sebuah fungsi. Pembelian berlaku untuk semua jenis bisnis dan bertujuan untuk mendapatkan bahan sesuai dengan pesanan, sedangkan departemen pengadaan sebagai salah satu bagian tim kerja suatu organisasi proyek, mempunyai kewajiban untuk bertanggung jawab atas proses pembelian itu sendiri, penanganan fungsi bahan yang merupakan hasil pembelian, dan juga kemungkinan bertanggung jawab atas kegiatan lain yang berhubungan dengan pembelian.

Secara lebih terperinci, fungsi pembelian bahan konstruksi dapat berupa:

1. Fungsi biaya

Pembelian bahan konstruksi berusaha untuk melakukan penghematan anggaran atau biaya sebuah proyek konstruksi dari segi bahan, di mana seperti yang telah disebutkan sebelumnya bahwa bahan konstruksi mempunyai bobot besar terhadap biaya sebuah proyek. Menurunkan biaya bahan konstruksi merupakan langkah efektif untuk menurunkan anggaran pengeluaran sebuah proyek, sehingga diperoleh keuntungan secara materi dari keseluruhan pelaksanaan proyek konstruksi. Penghematan dilakukan tanpa mengurangi kualitas bahan yang akan dibeli adalah hal penting, agar tidak mengurangi kualitas bangunan yang dihasilkan.

2. Fungsi perolehan

Ini merupakan fungsi untuk mengadakan jumlah pasokan bahan yang dibutuhkan untuk memenuhi kebutuhan pelaksanaan kegiatan konstruksi. Dalam pelaksanaan pembangunan, yang diperlukan adalah bagaimana penyerahannya ke lini pelaksanaan proyek konstruksi. Hal yang terpenting untuk mendapat perhatian adalah agar pemesanan bahan konstruksi dari perusahaan supplier dapat diterima sesuai dengan jumlah dan spesifikasi bahan yang dipesan, mutu standar, dan waktu penyerahan sesuai dengan yang telah dijadwalkan dalam surat pemasaran. 


\subsubsection{Perencanaan Pembelian}

Rencana pembelian harus dibuat dengan mempertimbangkan semua aspek terkait agar hasil yang diperoleh sesuai dengan fungsi pembelian sebagaimana telah dibahas pada sub bab sebelumnya. Perencanaan pembelian bahan konstruksi meliputi perencanaan spesifikasi bahan, perencanaan kuantitas, perencanaan waktu pengadaan, dan perencanaan biaya yang akan dikeluarkan untuk pembelian bahan.

Dalam perencanaan pembelian, departemen pengadaan dapat bekerja sama dengan pihak lain terkait, seperti bagian keuangan dan konsultan perencana. Oleh kerena itu, semua pihak pendukung pelaksanaan proyek harus dapat bekerja sebagai satu kesatuan yang utuh.

\subsubsection{Perencanaan Spesifikasi Bahan}

Spesifikasi bahan berupa perincian tentang mutu atau kualitas, ukuran, warna, dan jenis bahan yang akan dibeli. Spesifikasi bahan konstruksi biasanya telah ditetapkan dalam rencana kerja dan syarat-syarat pekerjaan suatu proyek konstruksi, yang dibuat oleh konsultan perencana atau pihak lain yang merencanakan proyek. Namun dalam pelaksanaan pembelian, sering kali spesifikasi yang terdapat pada rencana kerja proyek kurang jelas dan bila hal ini terjadi, pihak manajemen bahan harus dapat menentukan secara jelas spesifikasi bahan yang akan dibeli.

Selain itu, sering kali spesifikasi bahan yang terdapat dalam rencana kerja proyek tidak dapat diperoleh, terlalu mahal, ataupun tidak sesuai penggunaannya untuk pelaksanaan pekerjaan yang bersangkutan. Untuk mengatasi hal ini, pihak manajemen bahan harus dapat merencanakan ulang bahan yang akan dibeli dengan persetujuan pihak terkait, seperti konsultan perencana, pengawas lapangan, kontraktor pelaksana, atau owner. Perencanaan ulang bahan harus memperhatikan syarat-syarat penggantian bahan konstruksi yang tertera pada rencana kerja proyek, misalnya: kekuatan bahan pengganti tidak boleh lebih kecil dari kekuatan bahan rencana, biaya tambahan pembelian bahan merupakan tanggungan kontraktor pelaksana proyek, spesifikasi lain (ukuran, warna dan jenis) dari bahan pengganti tidak boleh berbeda jauh dari spesifikasi bahan rencana, dan lain-lain.

\subsubsection{Perencanaan Jumlah Bahan}

Evaluasi Pengadaan Bahan Konstruksi Pada Proyek Rumah Sakit Unggul Karsa Medika (Maksum Tanubrata, Rian Adhita Trisyandi) 
Perencanaan kuantitas atau jumlah bahan konstruksi yang akan dibeli sangat penting, karena kuantitas bahan sangat berpengaruh pada biaya yang akan dikeluarkan untuk pembelian bahan. Jumlah bahan konstruksi yang akan dibeli harus direncanakan dengan memperhatikan hal-hal sebagai berikut:

1. Jumlah kebutuhan bahan untuk pelaksanaan proyek;

2. Kemungkinan adanya bahan yang tidak dapat digunakan (waste material);

3. Kapasitas penyimpanan bila bahan tidak langsung digunakan.

Berdasarkan ketiga hal di atas, departemen pengadaan melakukan perhitungan jumlah bahan konstruksi untuk keperluan pelaksanaan proyek dengan mempertimbangkan jumlah bahan konstruksi untuk keperluan perencanaan, persediaan, jadwal, dan penerimaan.

Pengaturan jumlah persediaan bahan pada kondisi optimum perlu diperhatikan agar tidak terjadi persediaan berlebihan, sehingga merugikan dari segi biaya yang telah dikeluarkan. Selain itu, persediaan yang tidak mencukupi kebutuhan kegiatan pembangunan akan mengakibatkan terhentinya proses pelaksanaan proyek, ini akan mengakibatkan pekerja di lapangan menganggur dan bagian pekerjaan yang seharusnya dapat dilaksanakan menjadi tertunda, sehingga waktu pelaksanaan proyek tidak dapat berjalan sesuai dengan time schedule.

\subsubsection{Perencanaan Waktu Pengadaan}

Waktu pelaksanaan setiap pekerjaan proyek memerlukan bahan konstruksi tertentu sangat penting untuk diketahui karena bahan yang dibutuhkan harus tersedia pada saat pekerjaan akan dilakukan. Setelah mengetahui jadwal pelaksanaan masing-masing bagian pekerjaan, pihak manajemen bahan harus mengetahui berapa lama waktu yang dibutuhkan sejak perencanaan pembelian bahan sampai bahan siap digunakan, biasanya disebut dengan lead time. Dengan mengukur waktu pelaksanaan pekerjaan di lapangan dengan lead time bahan, maka proyek diharapkan dapat berjalan sesuai time schedule.

Dengan memperhitungkan lead time untuk semua jenis bahan konstruksi yang akan dipesan maka akan terhindar dari ketidakpastian supply bahan dari perusahaan pemasok karena perusahaan pemasok memiliki waktu cukup dalam mempersiapkan proses produksinya. Beberapa macam lead time adalah:

1. Lead time untuk persiapan dokumen

Merupakan periode antara diputuskannya jumlah bahan yang akan dibeli untuk digunakan dalam pelaksanaan proyek sampai dengan saat dikeluarkan surat pemesanan oleh departemen pengadaan. Perencanaan kuantitas bahan yang diperlukan 
harus dilakukan seakurat mungkin untuk menghindari kemungkinan kekurangan atau kelebihan bahan. Periode ini harus dapat dilakukan dengan sesingkat mungkin agar dapat mempersingkat lead time secara keseluruhan koordinasi antara bagian terkait harus dilakukan dengan baik.

\section{Lead time pengadaan}

Merupakan waktu saat dikeluarkan surat pemesanan sampai dengan waktu saat penyerahan material untuk pertama kalinya. Periode ini harus mempertimbangkan waktu yang diperlukan perusahaan supplier untuk mempersiapkan bahan konstruksi yang dipesan oleh pembeli. Hal yang perlu dipertimbangkan adalah bahwa untuk menyediakan bahan konstruksi tertentu, perusahaan supplier mempunyai tahapan pelaksanaan siklus produksi, yaitu waktu yang dibutuhkan untuk melakukan persiapan pengadaan bahan baku dan waktu untuk memproduksi bahan, misal kuda-kuda dari baja, supplier harus mempersiapkan bahan baja untuk proses produksinya dan waktu untuk menghasilkan kuda-kuda baja sesuai spesifikasi pembeli.

3. Lead time untuk memajukan pengiriman

Adalah periode antara saat penerimaan bahan sampai bahan sampai saat dimulainya pelaksanaan pekerjaan bagian proyek konstruksi yang membutuhkan bahan tersebut. Periode ini diperlukan untuk proses inspeksi penerimaan, proses inventarisasi, dan penyimpanan. Dalam periode ini juga harus mempertimbangkan risiko terhadap kemungkinan terjadinya penundaan oleh supplier.

Lead time pengadaan merupakan bagian sangat penting dalam lead time pelaksanaan proyek konstruksi secara keseluruhan. Mengingat adanya keragaman sifat masing-masing bahan konstruksi, bagian pengadaan harus mengenal dengan baik sifat setiap jenis bahan konstruksi dengan mengelompokkannya menjadi beberapa kelas, kemudian dapat ditentukan standar lead time pengadaan.

\subsubsection{Perencanaan Biaya Bahan}

Biaya yang digunakan untuk bahan konstruksi sangat berpengaruh pada biaya proyek secara keseluruhan, oleh karena itu perencanaan harga bahan yang akan dibeli sangat diperlukan untuk mengurangi budget proyek yang berlebihan dari sektor bahan. Berdasarkan proses pengadaan bahan, biaya bahan konstruksi terdiri atas:

1. Biaya pembelian, berupa biaya yang dikeluarkan untuk membeli bahan dari pihak supplier, termasuk biaya administrasi, harga bahan, dan keuntungan lain bagi supplier.

Evaluasi Pengadaan Bahan Konstruksi Pada Proyek Rumah Sakit Unggul Karsa Medika (Maksum Tanubrata, Rian Adhita Trisyandi) 
2. Biaya penyerahan, berupa biaya pengantaran bahan ke lokasi proyek atau ke tempat penyimpanan. Biaya ini tidak diperlukan apabila kontrak pembelian sudah termasuk pengantaran bahan, dimana supplier bertanggung jawab atas pengantaran bahan.

3. Biaya penyimpanan, yaitu biaya yang diperlukan selama proses penyimpanan bahan, baik di lokasi proyek ataupun di tempat penyimpanan lain.

Penyederhanaan sistem administrasi, penjadwalan penerimaan, dan pengaturan jumlah material yang baik, merupakan hal-hal yang perlu dilakukan untuk penghematan biaya bahan.

\subsubsection{Pembelian Bahan (Material Purchasing)}

Tindak lanjut kegiatan perencanaan bahan adalah pembelian. Hal-hal yang perlu dilakukan dalam proses pembelian bahan meliputi: pencarian informasi dipasaran tentang bahan yang akan dibeli, pemilihan pemasok bahan, dan transaksi pembelian. Ketiga proses pembelian tersebut harus dilakukan dengan baik dan dikontrol dengan cermat agar dapat diperoleh bahan sesuai dengan aspek-aspek yang ada pada proses perencanaan bahan.

\subsubsection{Informasi Bahan}

Informasi tentang bahan yang akan dibeli berupa keterangan tentang spesifikasi bahan, gambar, harga bahan, dan yang paling penting yaitu bagaimana proses produksi bahan berlangsung, serta informasi kasus didapat dari berbagai sumber, seperti media cetak atau media elektronik yang disajikan oleh supplier dalam berbagai bentuk iklan atau melalui pemantauan oleh pihak pembeli ke toko atau pabrik penyedia bahan.

Informasi bahan yang akurat sangat diperlukan dalam pengambilan keputusan berkaitan dengan jenis bahan dan supplier yang akan dipilih. Misalkan dalam pembelian pipa PVC, bentuk standar pipa, kualitas sesuai dengan rencana pembelian, serta harga sesuai dengan spesifikasi pipa dan tidak melampaui biaya bahan yang telah direncanakan merupakan syarat-syarat dari pipa yang akan dipilih. Untuk itu informasi akurat pipa sangat diperlukan agar pipa yang dibeli benar-benar sesuai dengan segala aspek yang telah direncanakan dan dapat dipergunakan dengan baik untuk pelaksanaan proyek.

Selain pencarian informasi bahan, kontrol terhadap informasi yang telah didapatkan merupakan langkah penting untuk dilakukan agar isi informasi tersebut benarbenar akurat dan dapat dipercaya. Kontrol terhadap informasi bahan antara lain berupa adanya kemungkinan perubahan isi informasi akibat adanya ketidaksesuaian antara hasil pemantauan langsung dengan data informasi sebelumnya. 


\subsubsection{Pemilihan Supplier}

Supplier yang baik adalah sumber berharga bagi pelaksanaan proses pembelian bahan konstruksi. Supplier atau pemasok bahan yang baik akan memberikan kontribusi terhadap suksesnya suatu pengadaan bahan. Supplier dapat membantu pelanggan dengan pengembangan kualitas produk yang disediakan, analisis harga bahan, dan pengantaran sesuai jadwal yang telah disepakati. Membina hubungan baik antara pembeli dengan supplier merupakan usaha dari pembeli untuk mendapatkan kinerja baik, layanan ekstra (extra service), program pengurangan harga, dan kemauan untuk membagi pengetahuan baru mengenai proses dan prosedur pembelian bahan dari supplier.

Pemilihan supplier yang tepat merupakan kunci untuk mendapatkan penyediaan bahan dengan kualitas yang diharapkan, tepat waktu, harga yang sesuai, dukungan teknis (seperti: petunjuk penggunaan bahan yang baik dan penyediaan fasilitas tambahan), dan pelayanan sesuai dengan yang diharapkan. Pembeli harus melakukan enam langkah penting untuk mendapatkan supplier yang tepat, yaitu:

1. Memelihara hubungan baik dan mengembangkan pemasok bahan utama, yang sebelumnya telah dapat memenuhi syarat sebagai supplier yang tepat;

2. Pelajari data supplier, kemudian terapkan strategi dan prosedur pemilihan yang tepat untuk mendapatkan supplier qualified (memenuhi syarat);

3. Calon supplier harus dievaluasi dengan teliti dan mempunyai potensi untuk menjadi rekan pemasok yang dapat memuaskan pembeli;

4. Putuskan apakah memilih supplier dengan cara memantau persaingan antara calon pemasok atau dengan melakukan negosiasi dengan calon supplier;

5. Lakukan penilaian kelayakan kerja sama dan pilih supplier yang tepat;

6. Tangani supplier terpilih untuk memastikan adanya pengantaran bahan tepat waktu dengan kualitas diinginkan dan harga sesuai.

Pembeli harus dapat memelihara hubungan baik dan mengembangkan pemasok bahan utama, agar pemasok benar-benar dapat memenuhi keinginan pembeli. Beberapa aspek penting yang perlu diperhatikan dalam rangka melakukan seleksi terhadap supplier adalah:

1. Status perusahaan supplier;

2. Struktur organisai perusahaan;

3. Nilai aset;

4. Lokasi perusahaan;

5. Jenis produksi;

Evaluasi Pengadaan Bahan Konstruksi Pada Proyek Rumah Sakit Unggul Karsa Medika (Maksum Tanubrata, Rian Adhita Trisyandi) 
6. Jenis dan jumlah peralatan produksi;

7. Pelanggan-pelanggan dari supplier;

8. Perolehan material;

9. Sistem pengendalian proses produksi;

10. Sistem pengendalian kualitas oleh supplier.

Beberapa aspek di atas sebaiknya dipelajari dengan baik untuk menyusun strategi dan prosedur yang tepat dalam pemilihan supplier. Informasi mengenai supplier merupakan elemen penting untuk penentuan supplier terpilih. Departemen pengadaan harus menyimpan informasi mengenai supplier, baik aktual atau yang terdahulu, antara lain berisi nama setiap pemasok, catatan proses pengantaran bahan oleh pemasok, sifat keseluruhan masing-masing supplier, dan informasi umum lainnya masing-masing supplier atau pemasok bahan konstruksi. Penilaian terhadap supplier dapat dilakukan melalui dua tahap, pertama berupa penilaian berdasarkan data supplier yang terdapat pada informasi supplier. Setelah data dipelajari dengan baik, maka tahap berikutnya dapat berupa tahap kunjungan ke perusahaan supplier untuk melakukan penelitian lebih lanjut.

Dalam proses pembelian, maksud baik pelanggan merupakan kunci suksesnya satu penyedia bahan atau supplier, karena maksud baik pelanggan berdampak langsung pada tingkat penjualan penyedia bahan. Tetapi perlu juga diketahui bahwa maksud baik supplier juga merupakan elemen penting yang menentukan sukses tidaknya suatu manajemen bahan konstruksi. Supplier mendapatkan maksud baik pelanggannya dengan cara menjual bahan konstruksi yang dapat diterima pada harga pantas, didukung dengan pelayanan memuaskan di mana akan diingat oleh pelanggan. Sedangkan pembeli mendapatkan maksud baik supplier dengan menjadi terbuka, bersikap tidak memihak, dan sangat adil dalam semua transaksi dengan supplier.

Pemilihan supplier bahan konstruksi harus dikontrol agar proses pemilihan dapat berjalan dengan benar dan sesuai dengan prosedur atau cara-cara pemilihan yang telah ditetapkan, sehingga supplier terpilih dapat memenuhi keinginan pembeli dan proses pengadaan bahan konstruksi dapat berjalan dengan lancar.

\subsubsection{Transaksi Pembelian}

Transaksi pembelian bahan konstruksi dilakukan setelah bagian pengadaan bahan menetapkan jenis bahan dan supplier terpilih. Transaksi pembelian didahului dengan penandatanganan kontrak pembelian dan diikuti dengan pelaksanaan kontrak pembelian. Kontrak pembelian bahan konstruksi antara lain berisi: spesifikasi bahan, jumlah bahan, harga, syarat dan waktu pembayaran, dan tanggal pengiriman bahan ke lokasi proyek atau 
tempat penyimpanan sementara (jika pengiriman dilakukan oleh supplier), serta memuat ketentuan-ketentuan lain sesuai kesepakatan kedua pihak selaku transaksi.

Kontrak pembelian perlu dibatasi masa berlakunya, meskipun nantinya dapat diperpanjang untuk beberapa periode, sesuai dengan hasil evaluasi yang dilakukan secara berkala tentang kondisi kerjasama yang dilakukan. Terhadap perusahaan supplier yang kinerjanya tidak memuaskan, tentu saja pembeli tidak akan memperpanjang kontrak. Kontrak pembelian yang telah ditandatangani oleh kedua pihak pelaku transaksi pembelian harus dipatuhi dan dilaksanakan, agar secara keseluruhan proses pembelian dapat berjalan dengan sukses.

\subsubsection{Pengiriman Bahan Konstruksi}

Pengiriman atau pengantaran bahan konstruksi dapat dilakukan oleh pihak supplier atau dilakukan sendiri oleh bagian manajemen bahan, sesuai dengan perjanjian yang tertera pada kontrak pembelian. Bila pengiriman dilakukan oleh pihak pemasok bahan, bagian pengadaan harus melakukan penyelidikan untuk memastikan bahwa bahan sesuai dengan pesanan dapat dikirim tepat pada waktu pengiriman yang terdapat pada kontrak pembelian. Jika hasil penyelidikan menyatakan bahwa supplier tidak dapat menyerahkan bahan pesanan pada waktu dan tempat yang tepat, maka bagian pengadaan harus segera mengambil langkah-langkah untuk menyelesaikan masalah tersebut. Langkah-langkah tersebut dapat berupa:

a. Merubah bahan pesanan (misalnya: merubah merek, ukuran, atau spesifikasi lainnya), bila perubahan ini disetujui oleh pihak perencana, owner, pengawas lapangan, ataupun kontraktor pelaksana dan dapat digunakan untuk pelaksanaan proyek;

b. Membatalkan pesanan dan menggantinya dengan supplier lain;

c. Mencari alternatif pihak yang dapat menerima bahan yang telah terlanjur dipesan.

Selain itu untuk menghindari pengiriman bahan yang tidak sesuai dengan spesifikasi dan jumlah pesanan, bagian pengadaan dapat mengunjungi tempat supplier secara berkala untuk memantau perkembangan penyerahan bahan pesanan oleh supplier. Pemantauan dapat berupa pengujian terhadap bahan di tempat supplier. Dalam proses pengiriman, jika bahan dibeli dari luar negeri, persetujuan bea cukai, pembayaran tarif impor, izin impor, dan lain-lain harus diatur dengan baik oleh bagian pengadaan.

Pengiriman bahan sangat berpengaruh pada mutu dan waktu persediaan bahan, oleh karena itu kontrol terhadap proses pengiriman bahan harus dilakukan dengan baik untuk memastikan pengiriman sesuai jadwal dan cara pengiriman tidak mengurangi mutu bahan. Pengawasan terhadap pemeliharaan mutu bahan pada saat pengiriman sampai 
bahan diterima, merupakan salah satu usaha kontrol terhadap proses pengiriman bahan perlu untuk dilakukan. Pengiriman yang tidak sesuai dengan jadwal rencana dapat menyebabkan keterlambatan pelaksanaan pekerjaan dan secara menyeluruh akan menyebabkan pembangunan yang tidak efisien dan tidak ekonomis.

\subsection{Penerimaan, Penyimpanan, dan Pengeluaran Bahan Konstruksi}

Setelah pengiriman bahan konstruksi dari tempat supplier ke lokasi proyek atau tempat penyimpanan bahan, bagian penting proses manajemen bahan adalah penerimaan bahan. Setelah penerimaan bahan disetujui oleh pihak manajemen bahan konstruksi proyek, bahan sepenuhnya telah menjadi tanggung jawab pihak pelaksana proyek, kecuali dalam surat perjanjian kontrak pembelian terdapat ketentuan-ketentuan lain, seperti adanya garansi penggunaan bahan. Pemeriksaan bahan yang teliti sangat diperlukan sebelum bahan diputuskan untuk diterima.

Penyimpanan bahan dilakukan setelah penerimaan bahan dan sebelum bahan diserahkan ke bagian pelaksanaan pekerjaan proyek. Dalam proses penyimpanan, bahan juga dipersiapkan agar dapat dipergunakan saat pekerjaan konstruksi akan dilakukan. Penetapan prosedur penyimpanan masing-masing bahan sangat penting untuk menjamin perawatan bahan, sehingga mutu bahan tidak berkurang bahkan mungkin bertambah saat akan digunakan.

Pengeluaran bahan untuk diserahkan ke lini pelaksanaan proyek harus dilakukan tepat pada saat bahan dibutuhkan agar pekerjaan proyek tidak tertunda akibat bahan yang dibutuhkan belum tersedia. Pengeluaran bahan dan penyerahan ke lini pelaksanaan proyek harus dilakukan dengan benar agar tidak merusak bahan atau mengganggu pelaksanaan pekerjaan.

\subsubsection{Penerimaan Bahan}

Jika pengiriman dilakukan oleh pihak supplier, sebelum bahan dibongkar dari kendaraan pengirim, bagian manajemen bahan harus memeriksa terlebih dahulu bahan yang ada. Jika pengiriman dilakukan sendiri oleh pihak pengadaan bahan, pemeriksaan dilakukan sebelum bahan diangkut dari tempat supplier. Langkah-langkah pemeriksaan bahan konstruksi sebelum bahan diputuskan untuk diterima adalah:

1. Memeriksa kondisi atau penampilan secara keseluruhan bahan. Pastikan bahan berada dalam kondisi baik, pisahkan bahan-bahan yang telah mengalami kerusakan atau cacat dan kembalikan ke supplier; 
2. Cocokkan spesifikasi dan jumlah bahan yang dipesan dengan bahan yang disediakan oleh supplier. Gunakan surat pesanan untuk memastikan jumlah, ukuran, jenis, kualitas atau mutu bahan yang tersedia telah sesuai dengan yang tertera dalam surat pesanan;

3. Pastikan bahwa bahan telah diuji oleh pihak supplier dan pengujian harus dilakukan dengan benar dan sesuai dengan standar pengujian yang ada;

4. Bila pengujian belum dilakukan atau untuk menjamin kualitas atau mutu bahan, dapat dilakukan dengan mengambil sampel bahan yang ada. Pengujian dapat dilakukan di lapangan atau di laboratorium, seperti: uji slump di lapangan, pengujian kuat tekan beton dan kuat tarik baja di laboratorium, dan lain-lain.

Ketelitian pada saat pemeriksaan akhir sebelum bahan diterima sangat dibutuhkan agar tidak terjadi kerugian dari segi kualitas ataupun segi kuantitas bahan. Selain itu, pastikan juga bahwa waktu penerimaan bahan telah sesuai dengan jadwal yang terdapat pada kontrak pembelian agar waktu persediaan bahan dapat sesuai dengan pelaksanaan pekerjaan proyek.

\subsubsection{Penyimpanan Bahan}

Setelah bahan dikirim ke proyek atau tempat penyimpanan, bahan harus dijaga dengan penyimpanan yang baik sebelum diserahkan ke bagian pelaksanaan pekerjaan proyek. Bahan-bahan yang digunakan proyek membutuhkan biaya cukup besar untuk mencegah terjadinya kehilangan atau kerusakan bahan-bahan yang tidak dapat digunakan (waste material). Proses penyimpanan merupakan faktor utama yang harus diperhatikan.

Aspek utama manajemen bahan konstruksi selama rentang waktu antara bahan diterima sampai bahan dikeluarkan setiap saat bila dibutuhkan adalah keamanan dan kesiapan. Keamanan selama proses penyimpanan bahan dan kesiapan yang meliputi kesiapan untuk menerima bahan dan kesiapan untuk menyerahkannya ke bagian pelaksanaan pekerjaan merupakan dua hal penting dalam proses penyimpanan bahan. Perhatian khusus harus diberikan untuk penyimpanan secara benar dan aman terhadap bahan-bahan yang mudah dicuri. Bahan-bahan tersebut harus disimpan pada tempat yang terbatas pencapaiannya.

Ruang penyimpanan bahan merupakan salah satu sumber daya proyek, perencanaan dan penyediaan ruangan yang tepat harus dilakukan sebelum bahan diterima. Dalam proses penyimpanan, bahan harus disiapkan agar dapat digunakan tepat waktu pelaksanaan pekerjaan, misalnya pasir harus disiapkan dalam keadaan saturated surface dry (SSD) sebelum digunakan untuk pembuatan adukan beton.

Evaluasi Pengadaan Bahan Konstruksi Pada Proyek Rumah Sakit Unggul Karsa Medika (Maksum Tanubrata, Rian Adhita Trisyandi) 
Pengenalan karakter setiap jenis bahan harus dilakukan sebelum bahan disimpan. Beberapa jenis bahan harus disimpan ditempat tertutup untuk melindungi bahan dari kerusakan akibat cuaca (misalnya: semen, bahan-bahan jenis logam, dan lain-lain). Selain itu ada juga bahan yang dapat disimpan ditempat terbuka. Bahan-bahan ini harus disimpan pada tempat yang telah disiapkan sebelumnya (sesuai karakter dan ukuran bahan) untuk menghindari kerusakan dan keausan bahan. Bahan harus diatur dan disusun dengan benar agar pengeluaran bahan dapat dilakukan dengan mudah. Kayu, tiang pancang, batu bata, dan lain-lain harus disusun dengan benar dan aman agar tidak menimbulkan kecelakaan pada saat pelaksanaan pekerjaan di lokasi proyek.

Pengelompokkan dan pengaturan bahan menurut umur penyimpanan sangat penting untuk dilakukan, misalnya semen yang telah lama didatangkan harus digunakan terlebih dahulu dibandingkan semen baru. Agar rotasi penggunaan bahan dengan usia lebih lama dapat dilakukan terlebih dahulu, misalnya dalam satu gudang dibuat dua pintu, satu pintu merupakan pintu untuk memasukkan bahan sesuai usia penyimpanan dapat dilakukan.

Setiap partai bahan harus ditandai dengan identifikasi yang jelas, agar tidak menimbulkan kesalahan pada saat pengeluaran bahan dilakukan. Setiap komponen bahan harus langsung diberi nomor yang benar begitu bahan diterima masuk ke ruang penyimpanan, sehingga pengenalan dapat dilakukan dengan sederhana, asal tanda identifikasi bahan tidak lepas dari bahannya.

Prosedur penyimpanan setiap bahan sebaiknya ditetapkan dengan jelas, sehingga kontrol terhadap proses penyimpanan bahan dapat dilakukan dengan mudah dan berlandaskan setiap langkah dan ketentuan prosedur penyimpanan yang ada. Dengan adanya kontrol atau pengawasan berkala terhadap penyimpanan bahan, diharapkan bahan dapat digunakan dalam kondisi mutu fisik yang baik serta dapat tersedia sesuai dengan waktu pelaksanaan pekerjaan proyek.

\subsubsection{Pengeluaran bahan}

Bahan dikeluarkan dari tempat penyimpanan bila diperlukan untuk pelaksanaan pekerjaan proyek. Sebelum bahan dikeluarkan, pengguna bahan harus terlebih dahulu mengisi berita acara pengeluaran bahan yang berisi informasi sehubungan dengan jumlah dan jenis bahan yang diambil, maksud penggunaan bahan, dan lain-lain. Berita acara penggunaan bahan harus diperiksa oleh yang bertanggung jawab untuk menjamin:

a. Bahan yang diambil dari gudang dibutuhkan dan benar digunakan pada proyek;

b. Informasi yang terdapat dalam berita acara adalah benar. 
Bahan permanen yang digunakan tidak akan dikembalikan lagi ke tempat penyimpanan, tetapi bahan yang tidak permanen harus dikembalikan setelah pemakaian. Sebagai contoh cetakan baja, papan bekisting, kayu perancah, dan lain-lain, mungkin diambil dan dikembalikan ke tempat penyimpanan setelah digunakan. Pada pengeluaran bahan untuk diserahkan kebagian pelaksanaan pekerjaan dilakukan, bahan harus dijaga agar tidak mengalami kerusakan. Prosedur atau tahap-tahap pengeluaran bahan penting untuk dibuat agar bahan dapat dijaga kondisi dan mutunya sebelum dipakai dalam pelaksanaan pekerjaan proyek. Petugas pengawas lapangan harus mengontrol proses pengeluaran ini.

\subsection{Kontrol Terhadap Kualitas Bahan Konstruksi}

Dalam masa perkembangan industri jasa konstruksi yang kurang bergairah di Indonesia akibat perekonomian masyarakat yang tidak menguntungkan, seleksi terhadap perusahaan konstruksi yang dilakukan oleh konsumen semakin ketat. Ini tidak terlepas dari minimnya permintaan jasa konstruksi bila dibandingkan dengan perusahaan jasa konstruksi yang ada. Aspek penting yang menjadi dasar pemilihan terhadap perusahaan jasa konstruksi adalah biaya dan kualitas bangunan yang dihasilkan.

Harga suatu bangunan merupakan pertimbangan dasar konsumen untuk memilih lokasi tempat tinggal atau sarana bangunan lain. Setelah penetapan budget yang akan dikeluarkan untuk pembelian bangunan, kualitas bangunan adalah pertimbangan utama dalam pemilihannya. Terkadang konsumen dapat mengabaikan harga demi mendapatkan suatu bangunan yang terbangun dari bahan-bahan berkualitas tinggi dan tentu mempunyai usia pakai relatif lama. Selain usia pakai lama, kualitas suatu bangunan juga menciptakan perasaan nyaman bagi penghuni atau penggunanya. Kenyamanan merupakan faktor penting yang perlu disediakan oleh perusahaan jasa konstruksi untuk bersaing dalam merebut pasar konstruksi yang semakin minim.

Perhatian penuh terhadap kualitas bahan bangunan akan memberikan dampak positif kepada bisnis jasa konstruksi melalui dua cara, yaitu: dampak terhadap biaya produksi dan dampak terhadap pendapatan. Dampak terhadap produksi melalui proses pembangunan proyek memiliki kepedulian tinggi terhadap standar-standar sehingga bahan dapat bebas dari tingkat kerusakan yang mungkin terjadi. Dengan demikian proses pembangunan yang memperhatikan kualitas akan menghasilkan bangunan berkualitas yang bebas dari kerusakan. Ini berarti terhindar dari pemborosan dan menciptakan efisiensi sehingga biaya untuk bahan yang tidak dapat digunakan dapat dikurangi. Dampak terhadap peningkatan pendapatan terjadi melalui peningkatan pelanggan proyek atas bangunan berkualitas yang berharga kompetitif.

Evaluasi Pengadaan Bahan Konstruksi Pada Proyek Rumah Sakit Unggul Karsa Medika (Maksum Tanubrata, Rian Adhita Trisyandi) 
Untuk mendapatkan kualitas bahan konstruksi yang memadai sehingga dapat dihasilkan bangunan berkualitas, bahan yang akan digunakan untuk proses pembangunan harus dikontrol kualitasnya. Kontrol terhadap kualitas bahan dapat dilakukan dengan:

1. Pengembangan manajemen kualitas sebuah perusahaan;

2. Kontrol terhadap proses produksi bahan yang akan dibeli dan digunakan;

3. Kontrol terhadap pemeriksaan dan pengujian bahan konstruksi.

Kontrol dapat dilakukan oleh bagian pengadaan dan bagian pengawasan di lapangan. Kontrol yang baik terhadap kualitas bahan merupakan senjata utama dalam mewujudkan suatu manajemen bahan konstruksi yang handal untuk menciptakan keberhasilan pelaksanaan proyek dan pembangunan suatu perusahaan jasa konstruksi.

\subsubsection{Pemeriksaan Bahan}

\subsubsection{Pemeriksaan Bahan}

Pemeriksaan dilakukan untuk menjamin mutu bahan yang tersedia sesuai dengan jumlah pesanan dan spesifikasi rencana, sehingga dapat digunakan secara tepat untuk pekerjaan proyek. Selain itu pemeriksaan juga dilakukan untuk menjamin bahwa kualitas bahan yang ada tetap terjaga sampai bahan siap untuk digunakan. Dalam manajemen bahan konstruksi, pemeriksaan sebaiknya dilakukan pada hampir semua tahap proses manajemen bahan, yaitu:

1. Pemeriksaan pada saat proses produksi bahan;

2. Pemeriksaan pada saat bahan ditempat supplier (di toko, di gudang, atau tempat penyimpanan lain);

3. Pemeriksaan pada saat bahan akan dikirim ke proyek;

4. Pemeriksaan di tempat penyimpanan;

5. Pemeriksaan saat bahan dikeluarkan dan akan diserahkan ke bagian pelaksanaan pekerjaan.

Pemeriksaan yang baik adalah pemeriksaan meliputi keseluruhan bahan, sehingga bila ada sebagian bahan yang rusak dapat dipisahkan dan tidak digunakan untuk pekerjaan proyek. Catatan hasil pemeriksaan bahan dapat digunakan sebagai dasar pertimbangan untuk:

1. Penilaian terhadap supplier dan pengambilan keputusan pembelian bahan;

2. Penolakan terhadap bahan yang tidak sesuai dengan spesifikasi dan kualitas rencana;

3. Memutuskan apakah bahan yang tidak sesuai spesifikasi dan kualitas rencana disingkirkan, diperbaiki, atau diproduksi ulang. 
Langkah-langkah pemeriksaan suatu jenis bahan sebaiknya ditetapkan dan dijalankan dengan benar. Untuk menjamin bahwa pemeriksaan sudah dilakukan dengan benar, kontrol terhadap proses pemeriksaan yang meliputi hampir semua proses manajemen bahan konstruksi perlu untuk dilakukan. Kontrol yang dilakukan antara lain: menyesuaikan standar prosedur pemeriksaan yang dilakukan dengan standar (baik standar nasional ataupun standar lain), menetapkan pemeriksaan secara berkala, mengawasi langkah-langkah pemeriksaan yang dilakukan, memastikan adanya jaminan pengujian bahan yang dilakukan supplier bila bahan tidak diuji lagi, dan lain-lain.

Tabel 4.1 Proses dalam Analisis (lanjutan)

\begin{tabular}{|c|c|c|c|c|}
\hline N2.1 & $\begin{array}{l}\text { Metode } \\
\text { Pengendalian dan } \\
\text { Proses } \\
\text { PengadaanBahan }\end{array}$ & Prosedur & $\begin{array}{l}\text { Implementasi } \\
\text { di Proyek }\end{array}$ & Analisis \\
\hline 3 & $\begin{array}{l}\text { Pembuatan surat } \\
\text { permintaan } \\
\text { pembelian (SPP) }\end{array}$ & $\begin{array}{l}\text { Harus berisi data } \\
\text { yang } \\
\text { menguraikan } \\
\text { dengan jelas } \\
\text { produk yang } \\
\text { dipesan. }\end{array}$ & $\begin{array}{l}\text { SPP berisikan } \\
\text { Volume dan } \\
\text { waktu } \\
\text { pengiriman } \\
\text { atau } \\
\text { penerimaan } \\
\text { asal produk, } \\
\text { type, kelas, } \\
\text { model, } \\
\text { spesifikasi, } \\
\text { tingkat atau } \\
\text { identifikasi } \\
\text { tepat lainnya, } \\
\text { Nama atau } \\
\text { identifikasi } \\
\text { tepat lain }\end{array}$ & $\begin{array}{l}\text { Semua proses } \\
\text { pembuatan } \\
\text { SPP yang } \\
\text { dilakukan } \\
\text { tersebut sudah } \\
\text { sangat baik } \\
\text { dan teliti. } \\
\text { Surat } \\
\text { permintaan } \\
\text { pembelian. } \\
\text { Dapat dilihat } \\
\text { pada lampiran } \\
\text { L.3 }\end{array}$ \\
\hline 4.2 .2 & $\begin{array}{l}\text { Proses pembelian } \\
\text { bahan }\end{array}$ & $\begin{array}{l}\text { Tahapan ini } \\
\text { dilaksanakan } \\
\text { dengan urutan } \\
\text { sebagai berikut : } \\
\text { 1. Pengiriman } \\
\text { dan } \\
\text { pembelian } \\
\text { (logistic) } \\
\text { memutuskan } \\
\text { harga final; } \\
\text { 2. Menyiapkan } \\
\text { Surat } \\
\text { Pesanan (SP); }\end{array}$ & $\begin{array}{ll}\text { 1. } & \text { Ada } \\
\text { pembelian } \\
\text { yang } \\
\text { dilaksanak } \\
\text { an di } \\
\text { DVO. Ada } \\
\text { juga yang } \\
\text { melakukan } \\
\text { pembelian } \\
\text { langsung } \\
\text { di proyek; } \\
\text { 2. Dibuat } \\
\text { juga surat }\end{array}$ & $\begin{array}{l}\text { Proses } \\
\text { pembelian } \\
\text { bahan material } \\
\text { yang } \\
\text { dilakukan pada } \\
\text { proyek Rumah } \\
\text { Sakit Unggil } \\
\text { Karsa Medika } \\
\text { ini, sudah tepat } \\
\text { dan sudah } \\
\text { sesuai, hal ini } \\
\text { terlihat dari } \\
\text { adanya surat- }\end{array}$ \\
\hline
\end{tabular}

Evaluasi Pengadaan Bahan Konstruksi Pada Proyek Rumah Sakit Unggul Karsa Medika 


\begin{tabular}{|l|l|l|l|}
\hline & $\begin{array}{l}\text { 3. Memantau } \\
\text { pengiriman } \\
\text { bahan. }\end{array}$ & $\begin{array}{l}\text { pesanan } \\
\text { (SP). }\end{array}$ & $\begin{array}{l}\text { surat yang } \\
\text { berhubungan } \\
\text { dengan } \\
\text { pembelian } \\
\text { bahan material } \\
\text { mulai dari } \\
\text { surat } \\
\text { permintaan } \\
\text { pembelian } \\
\text { (SPP) sampai } \\
\end{array}$ \\
& & \\
& & $\begin{array}{l}\text { adanya surat } \\
\text { pesanan (SP). } \\
\text { Dapat dilihat } \\
\text { pada lampiran } \\
\text { L.3 }\end{array}$ \\
& & \\
& & \\
& & \\
& & \\
\end{tabular}

Tabel 4.1 Proses dalam Analisis (lanjutan)

\begin{tabular}{|c|c|c|c|c|}
\hline $\mathbf{N}$ & $\begin{array}{l}\text { Metode } \\
\text { Pengendalian } \\
\text { dan Proses } \\
\text { Pengadaan } \\
\text { Bahan } \\
\end{array}$ & Prosedur & $\begin{array}{l}\text { Implementasi } \\
\text { di Proyek }\end{array}$ & Analisis \\
\hline 4.2 .3 & $\begin{array}{l}\text { Proses } \\
\text { pengiriman } \\
\text { bahan }\end{array}$ & $\begin{array}{l}\text { Pada tahapan ini } \\
\text { kegiatan } \\
\text { penerimaan } \\
\text { bahan dapat } \\
\text { berfungsi antara } \\
\text { lain sebagai } \\
\text { pengendalian } \\
\text { material. Jika } \\
\text { memenuhi } \\
\text { syarat, bahan } \\
\text { disimpan } \\
\text { didalam gudang } \\
\text { dan dicatat } \\
\text { dalam Bon } \\
\text { Penerimaan } \\
\text { Gudang (BPG), } \\
\text { jika tidak bahan } \\
\text { ditolak. } \\
\text { Bahan harus } \\
\text { sesuai dengan } \\
\text { spesifikasi dan } \\
\text { kualitas yang }\end{array}$ & $\begin{array}{l}\text { Menerima surat } \\
\text { jalan dari } \\
\text { supplier, } \\
\text { pembuatan bon } \\
\text { penerimaan } \\
\text { gudang (BPG) } \\
\text { oleh penerima } \\
\text { barang, lalu } \\
\text { membuat berita } \\
\text { acara serah } \\
\text { terima barang, } \\
\text { untuk diberikan } \\
\text { pada supplier. } \\
\text { Lalu } \\
\text { mencatatnya di } \\
\text { kartu stock } \\
\text { harian. }\end{array}$ & $\begin{array}{l}\text { Semua tahapan } \\
\text { penerimaan } \\
\text { bahan } \\
\text { dilakukan } \\
\text { dengan teliti, } \\
\text { ini terbukti } \\
\text { dengan adanya } \\
\text { surat-surat yang } \\
\text { harus diisi oleh } \\
\text { petugas } \\
\text { penerima } \\
\text { barang, mulai } \\
\text { dari pengisian } \\
\text { bon penerimaan } \\
\text { gudang (BPG), } \\
\text { pembuatan } \\
\text { berita acara } \\
\text { serah terima } \\
\text { barang, dan } \\
\text { mengisi kartu } \\
\text { stock harian. } \\
\text { Dapat dilihat } \\
\text { pada lampiran }\end{array}$ \\
\hline
\end{tabular}




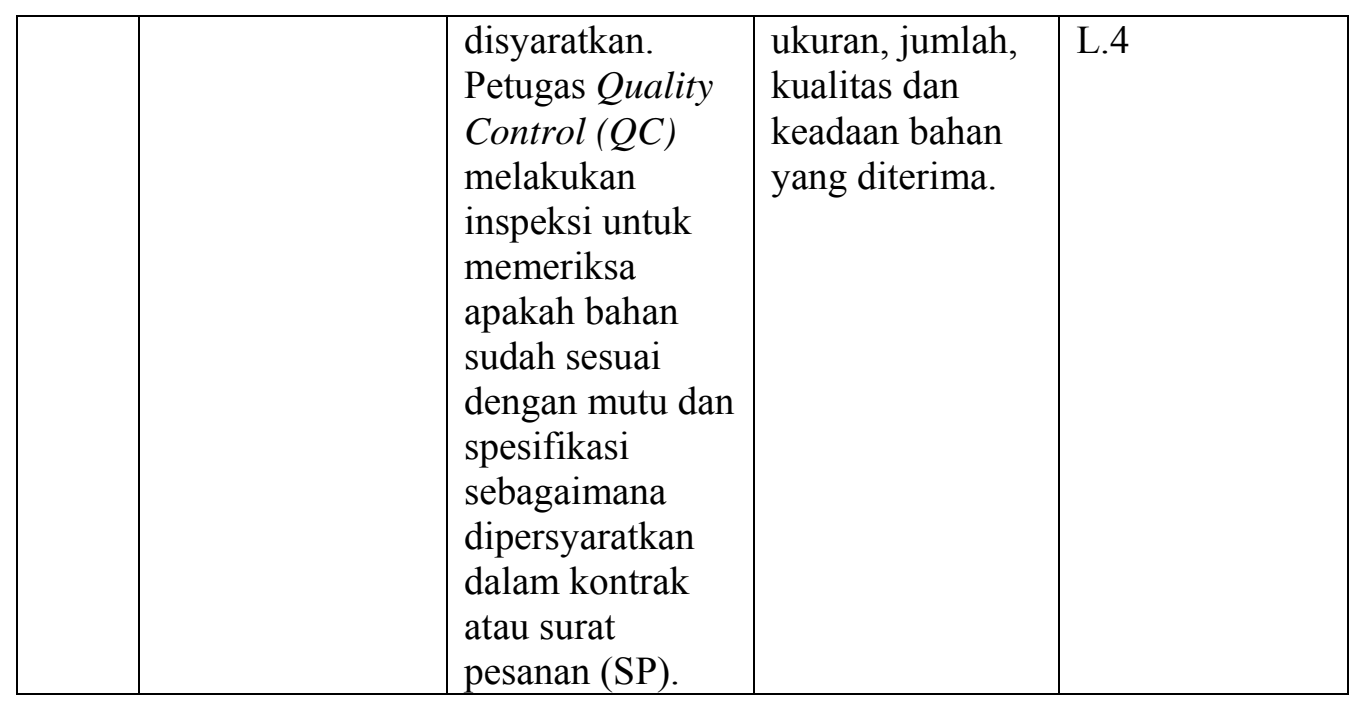

Tabel 4.1 Proses dalam Analisis (lanjutan)

\begin{tabular}{|c|c|c|c|c|}
\hline No & $\begin{array}{c}\text { Metode } \\
\text { Pengendalian } \\
\text { dan Proses } \\
\text { Pengadaan } \\
\text { Bahan } \\
\end{array}$ & Prosedur & $\begin{array}{l}\text { Implementasi } \\
\text { di Proyek }\end{array}$ & Analisis \\
\hline 4.2 .5 & $\begin{array}{l}\text { Proses } \\
\text { penyimpanan } \\
\text { bahan }\end{array}$ & $\begin{array}{l}\text { Hal yang perlu } \\
\text { dipertimbangkan } \\
\text { dalam } \\
\text { penyimpanan } \\
\text { bahan adalah } \\
\text { Ukuran material, } \\
\text { organisasi, } \\
\text { perlindungan, } \\
\text { keamanan, biaya, } \\
\text { dan kontrol }\end{array}$ & $\begin{array}{l}\text { Penyimpanan } \\
\text { barang-barang } \\
\text { kecil disimpan } \\
\text { dalam rak lalu } \\
\text { diberi nomor } \\
\text { kode label. } \\
\text { Disini } \\
\text { keselamatan } \\
\text { dan keamanan } \\
\text { dari bahan } \\
\text { yang ada di } \\
\text { dalam gudang } \\
\text { sangat } \\
\text { diperhatikan, } \\
\text { para petugas } \\
\text { gudangnya } \\
\text { selalu } \\
\text { mengunci dari } \\
\text { luar sehabis } \\
\text { jam kerja. } \\
\text { Gudang } \\
\text { tertutup ada } \\
\text { yang satu pintu }\end{array}$ & $\begin{array}{l}\text { Pada proyek } \\
\text { Rumah Sakit ini } \\
\text { telah } \\
\text { merencanakannya } \\
\text { dengan sedemikian } \\
\text { rupa agar } \\
\text { menghasilkan } \\
\text { suatu keadaan } \\
\text { yang benar-benar } \\
\text { optimum dan } \\
\text { efektif. }\end{array}$ \\
\hline
\end{tabular}




\begin{tabular}{|c|c|c|c|c|}
\hline & & & $\begin{array}{l}\text { dan ada yang } \\
\text { dua pintu. Ada } \\
\text { gudang semen } \\
\text { dan ada } \\
\text { gudang bahan. } \\
\text { Gudang } \\
\text { terbuka hanya } \\
\text { ada satu. } \\
\text { Ukurannya } \\
\text { sudah cukup } \\
\text { memadai. }\end{array}$ & $\begin{array}{l}\text { Rumah Sakit } \\
\text { Unggul Karsa } \\
\text { Medika, sudah } \\
\text { cukup memadai, } \\
\text { hal ini terbukti dari } \\
\text { adanya sebuah } \\
\text { tempat gudang } \\
\text { yang dikhususkan } \\
\text { untuk menyimpan } \\
\text { bahan dalam } \\
\text { berbagai ukuran, } \\
\text { yang dapat disusun } \\
\text { secara teratur dan } \\
\text { terkoordinir. Besi } \\
\text { dan kayu tidak } \\
\text { tahan cuaca dibuat } \\
\text { ruangan semi } \\
\text { tertutup, denah } \\
\text { gudang dapat } \\
\text { dilihat pada } \\
\text { lampiran L.5 }\end{array}$ \\
\hline
\end{tabular}

Tabel 4.1 Proses dalam Analisis (lanjutan)

\begin{tabular}{|c|l|l|l|l|}
\hline No & $\begin{array}{l}\text { Metode } \\
\text { Pengendalian } \\
\text { dan Proses } \\
\text { Pengadaan } \\
\text { Bahan }\end{array}$ & Prosedur & $\begin{array}{l}\text { Implementasi di } \\
\text { Proyek }\end{array}$ & Analisis \\
\hline Lokasi gudang & $\begin{array}{l}\text { Penentuan luas } \\
\text { ruang untuk } \\
\text { kebutuhan } \\
\text { penyimpanan } \\
\text { disesuaikan } \\
\text { dengan sistem } \\
\text { inventory yang } \\
\text { akan } \\
\text { diterapkan, } \\
\text { serta } \\
\text { kemampuan } \\
\text { luas lokasi } \\
\text { yang tersedia } \\
\text { ditempatkan di } \\
\text { kelakang direksi }\end{array}$ & $\begin{array}{l}\text { Geet } \\
\text { dilakukan sudah } \\
\text { sangat tepat. } \\
\text { Karena berada di } \\
\text { dalam proyek, } \\
\text { untuk menjaga } \\
\text { ketertiban dan } \\
\text { kebersihan, } \\
\text { posisinya tidak } \\
\text { disimpan didekat } \\
\text { pintu gerbang } \\
\text { proyek, tapi agak } \\
\text { masuk lagi } \\
\text { kedalam, lagi } \\
\text { pula jarak dari } \\
\text { pintu gerbang ke } \\
\text { lokasi gudang } \\
\text { lumayan jauh. }\end{array}$ \\
\hline
\end{tabular}




\begin{tabular}{|c|c|c|c|c|}
\hline & $\begin{array}{l}\text { Cara } \\
\text { penyimpanan }\end{array}$ & $\begin{array}{l}\text { Berdasarkan } \\
\text { karakteristik } \\
\text { sifat dari bahan }\end{array}$ & $\begin{array}{l}\text { Berdasarkan : } \\
\text { - Ukuran } \\
\text { - Sifat } \\
\text { - Merk/Type } \\
\text { - Jenis/fungsi }\end{array}$ & $\begin{array}{l}\text { Untuk barang- } \\
\text { barang yang kecil } \\
\text { dan aksesoris } \\
\text { yang gampang } \\
\text { hilang disimpan } \\
\text { secara teratur, } \\
\text { lalu agar mudah } \\
\text { mencarinya } \\
\text { barang-barang } \\
\text { tersebut diberi } \\
\text { label atau tanda } \\
\text { pengenal. }\end{array}$ \\
\hline 4.2 .6 & $\begin{array}{l}\text { Proses } \\
\text { pengeluaran } \\
\text { bahan }\end{array}$ & $\begin{array}{l}\text { Menyerahkan } \\
\text { bahan kepada } \\
\text { pemakai di } \\
\text { lapangan } \\
\text { berdasarkan } \\
\text { Bon } \\
\text { Permintaan } \\
\text { Pengeluaran } \\
\text { Bahan (BPPB) } \\
\text { dan } \\
\text { mencatatnya } \\
\text { pada kartu } \\
\text { stock } \\
\text { (persediaan } \\
\text { bahan). }\end{array}$ & $\begin{array}{l}\text { Dalam } \\
\text { pelaksanaannya } \\
\text { di lapangan } \\
\text { petugas penerima } \\
\text { barang tidak } \\
\text { membuat dan } \\
\text { mengisi bon } \\
\text { permintaan } \\
\text { pengeluaran } \\
\text { bahan (BPPB) } \\
\text { dan hanya } \\
\text { mencatatnya saja } \\
\text { pada kartu stock } \\
\text { harian. Dapat } \\
\text { dilihat pada } \\
\text { lampiran L. } 6\end{array}$ & $\begin{array}{l}\text { Hal tersebut } \\
\text { dikarenakan } \\
\text { percaya kepada } \\
\text { SDM yang ada } \\
\text { dan telah diawasi } \\
\text { oleh pihak } \\
\text { pelaksana. } \\
\text { Seharusnya } \\
\text { petugas membuat } \\
\text { bon permintaan } \\
\text { pengeluaran } \\
\text { bahan (BPPB), } \\
\text { hal ini } \\
\text { dimaksudkan } \\
\text { untuk } \\
\text { menghindari } \\
\text { kehilangan bahan } \\
\text { yang mungkin } \\
\text { saja terjadi dan } \\
\text { mempersempit } \\
\text { kesempatan } \\
\text { untuk melakukan } \\
\text { tindakan yang } \\
\text { tidak } \\
\text { bertanggung } \\
\text { jawab. }\end{array}$ \\
\hline
\end{tabular}

Tabel 4.1 Proses dalam Analisis (lanjutan)

\begin{tabular}{|c|l|l|l|l|}
\hline No & $\begin{array}{c}\text { Metode } \\
\text { Pengendalian } \\
\text { dan Proses } \\
\text { Pengadaan } \\
\text { Bahan }\end{array}$ & Prosedur & $\begin{array}{c}\text { Implementasi } \\
\text { di Proyek }\end{array}$ & Analisis \\
\hline 4.2 .7 & $\begin{array}{l}\text { Metode } \\
\text { Pengendalian }\end{array}$ & $\begin{array}{l}\text { Ada lima } \\
\text { metode, yaitu }\end{array}$ & $\begin{array}{l}\text { Pada proyek } \\
\text { Rumah Sakit }\end{array}$ & $\begin{array}{l}\text { Metode } \\
\text { pengendalian }\end{array}$ \\
\hline
\end{tabular}

Evaluasi Pengadaan Bahan Konstruksi Pada Proyek Rumah Sakit Unggul Karsa Medika 


\begin{tabular}{|c|c|c|c|}
\hline $\begin{array}{l}\text { Dalam } \\
\text { Memenuhi } \\
\text { Kebutuhan } \\
\text { Bahan di Proyek }\end{array}$ & $\begin{array}{ll}\text { 1. } & \text { Pembagian } \\
& \text { jenis barang } \\
\text { 2. } & \text { Prinsip } \\
& \text { Pareto dan } \\
& \text { aplikasinya } \\
\text { 3. } & \text { MRP } \\
\text { 4. } & \text { Titik } \\
& \text { pemesanan } \\
& \text { berdasarkan } \\
& \text { rentang } \\
& \text { waktu } \\
\text { 5. } & \text { Persediaan } \\
& \text { adalah } \\
& \text { pemborosan }\end{array}$ & $\begin{array}{l}\text { Unggul Karsa } \\
\text { Medika } \\
\text { memiliki } \\
\text { metode } \\
\text { pengendalian } \\
\text { sendiri yaitu } \\
\text { rapat. }\end{array}$ & $\begin{array}{l}\text { yang dilakukan } \\
\text { ini sudah cukup } \\
\text { baik, tapi hanya } \\
\text { fokus kepada } \\
\text { keseluruhan } \\
\text { kegiatan proyek } \\
\text { yang mana salah } \\
\text { satunya adalah } \\
\text { pemenuhan } \\
\text { kebutuhan bahan } \\
\text { di proyek. Jadi } \\
\text { dapat disimpulkan } \\
\text { bahwa metode ini } \\
\text { tidak fokus } \\
\text { kepada proses } \\
\text { pengadaan bahan } \\
\text { konstruksi. } \\
\text { Khusus untuk } \\
\text { pengadaan bahan } \\
\text { konstruksi sendiri } \\
\text { sudah mempunyai } \\
\text { pegangan yaitu } \\
\text { buku khusus } \\
\text { permintaan } \\
\text { material proyek, } \\
\text { yang di dalamnya } \\
\text { sudah mencakup } \\
\text { tentang kebutuhan } \\
\text { bahan sampai } \\
\text { kedatangan bahan } \\
\text { di proyek, } \\
\text { hubungannya } \\
\text { dengan metode } \\
\text { pengendalian } \\
\text { adalah hanya } \\
\text { membahas bentuk } \\
\text { perwujudannya } \\
\text { dilapangan, maka } \\
\text { dari itu rapat } \\
\text { tersebut dapat } \\
\text { dikatakan sebagai } \\
\text { metode } \\
\text { pengendalian } \\
\text { yang diterapkan } \\
\text { dalam pengadaan } \\
\text { bahan konstruksi. }\end{array}$ \\
\hline
\end{tabular}




\section{SIMPULAN DAN SARAN}

\subsection{Simpulan}

Dari hasil pengolahan analisis data yang telah dilakukan, simpulan yang dapat diambil adalah:

1. Tahap Perencanaan

a. Perencanaan bahan sudah dibuat diawal oleh kontraktor, mulai dari penjadwalan pendatangan material sampai pembuatan surat permintaan pesanan (SPP), namun dalam pelaksanaanya pengadaan bahan yang dilakukan lebih mengacu kepada jenis pekerjaan yang diberikan. Dengan demikian perencanaan bahan yang dibuat hanya sebagai pegangan untuk mengetahui lead time dan waktu perputaran bahan.

b. Pemilihan bahan bangunan sudah sesuai dengan spesifikasi kontrak dengan membeli bahan sesuai dengan shop drawing.

c. Pembuatan surat permintaan pembelian telah dibuat sesuai dengan data yang menguraikan dengan jelas produk yang dipesan.

2. Proses pembelian bahan yang telah dilakukan sudah tepat dan sesuai, hal ini terlihat dari adanya surat-surat pembelian bahan.

3. Proses pengiriman bahan dilakukan dengan baik, ini terbukti dengan adanya surat-surat yang harus diisi oleh petugas penerima barang. Pemeriksaan bahan dilakukan oleh quality control berdasarkan ukuran, jumlah, kualitas, dan keadaan bahan yang diterima.

4. Proses penyimpanan bahan dilakukan dengan baik terbukti proses penyimpanan berdasarkan dengan ukuran, sifat, merk, jenis, dan fungsinya. Penyimpanan dilakukan di gudang tertutup dan gudang terbuka dengan ukuran cukup memadai.

5. Proses pengeluaran bahan dalam pelaksanaan proyek ini tidak sesuai dengan prosedur karena petugas tidak membuat dan mengisi bon permintaan pengeluaran bahan tapi hanya mengisi kartu stok harian dikarenakan percaya kepada SDM yang ada.

6. Metode pengendalian yang dilakukan oleh kontraktor dalam proses pengadaan bahan di proyek adalah rapat mingguan. 


\subsection{Saran}

1. Sebaiknya pembuatan bon permintaan pengeluaran bahan harus dilakukan oleh petugas gudang, agar tidak terjadi kesalahpahaman tentang pengalokasian bahan dan mencegah terjadinya penyimpanan dalam pemakaian bahan yang sudah dikeluarkannya.

2. Untuk penelitian lebih lanjut, disarankan untuk membahas tentang kebijakan pada proses pengadaan bahan konstruksi dan biaya yang mencakup pengadaan bahan konstruksi.

\section{REFERENSI}

1. Aureline, 2008, Sistem Informasi Manajemen Bahan Pada Proyek Konstruksi Perumahan Setraduta, Jurusan Double Degree FT Universitas Kristen Maranatha, Bandung.

2. Dwiantara, L., dan Rumsari, S.H., 2004, Manajemen Logistik Pedoman Praktis Bagi Sekretaris dan Staf Administrasi”, Yogyakarta.

3. Darma, B., Wiranata, Nadiasa, M., 2013, Analisis Sistem Pengadaan Bahan dan Peralatan Pada proyek Konstruksi Jembatan Tukad Penet di Badung Bali, Jurusan Teknik Sipil FT Universitas Udayana, Denpasar.

4. Eko, R., Djokopranoto, R., 2002, Konsep Manajemen Supply Chain, Grasindo, Jakarta.

5. Evrianto, 2004, Aplikasi Manajemen Proyek Konstruksi, Andi, Yogyakarta.

6. Gaspersz, V., 1998, Production Planning and Inventory Control, PT Gramedia Pustaka Utama, Jakarta.

7. Hanna, E., Michael, R., Barry, dan Stair, R., 1997, Quantitattive Analysis for Management, New Jersey.

8. http://adman.staf.upi.edu/2012/07/27/konsep-manajemen-logistik.

9. http://ejournal.unsrat.ac.id/index.php/jss/article/download/1434/1136.

10. Kusuma, H., 2004, Manajemen Produksi.Andi, Yogyakarta.

11. Limbong, I., 2013, Manajemen Pengadaan Material Bangunan Dengan Menggunakan Metode MRP (Material Requirement Planing) Studi 
Khasus: Revitalisasi Gedung Kantor BPS Propinsi Sulawesi Utara, Jurusan Teknik Sipil, FT Universitas Sam Ratulangi, Manado. 